\section{How the validation of prior learning can be used to assess entrepreneurial human capital investments and outcomes}

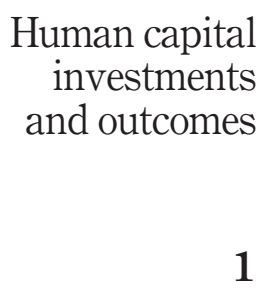

\author{
Florian Fahrenbach
}

Institute for Data, Process and Knowledge Management, Vienna University of Economics and Business, Vienna, Austria
Received 30 September 2019 Revised 20 August 2020 Accepted 7 December 2020

\begin{abstract}
Purpose - This paper aims to depart from the premise that human capital investments and human capital outcomes are often tacit - an aspect, which is often neglected in the current literature on entrepreneurial human capital. The idea of this conceptual paper is to shed light on the social process of how human capital investments and human capital outcomes can be valued and made visible through the validation of prior learning. Thus, this study conceptualises the validation of prior learning as a post hoc, the reflective process through which an aspiring entrepreneur is guided.
\end{abstract}

Design/methodology/approach - This paper is conceptual and introduces a process model.

Findings - Findings indicate that the process of the validation of prior learning is well-suitable to inform aspiring entrepreneurs of their investments into human capital and their human capital outcomes. The process results in a (partial) certified qualification that provides entrepreneurial legitimacy.

Research limitations/implications - Thus far, the model is conceptual and should be validated via interviews and further empirical studies in the field.

Practical implications - Literature in the field of entrepreneurial human capital suggests that human capital outcomes are more important for success than inputs. Furthermore, context-specific knowledge, skills and abilities are more important than generalised outcomes. These findings have implications for the design of validation procedures.

Originality/value - Human capital has only been recently conceptualised as consisting of human capital investments and outcomes of human capital investment. However, thus far the literature falls short in acknowledging the tacit nature of human capital investments and human capital outcomes. This paper contributes a structured process of how human capital investments and human capital outcomes are linked and assessed. In so doing, this study extends a recent model of human capital investments and outputs (Marvel et al., 2016, p. 616).

Keywords Human capital, Tacit knowledge, Validation of prior learning, Human capital investments, Human capital outcomes, Non-formal and informal learning

Paper type Conceptual paper

(C) Florian Fahrenbach. Published by Emerald Publishing Limited. This article is published under the Creative Commons Attribution (CC BY 4.0) licence. Anyone may reproduce, distribute, translate and create derivative works of this article (for both commercial and non-commercial purposes), subject to full attribution to the original publication and authors. The full terms of this licence maybe seen at http://creativecommons.org/licences/by/4.0/legalcode

The author was partially funded by the EU H2020 program under MSCA-RISE agreement 645751 (RISE BPM) and FFG Austrian Research Promotion Agency (project number: 866270). I am grateful for constructive feedback on earlier drafts of the manuscript at the European Conference on Knowledge Management (ECKM) 2019 and for the constructive feedback of two anonymous referees. 
EJTD

47,10

\section{Introduction}

Human capital has been used to analyse and explain phenomena ranging from individuals to complex social systems (Schultz, 1961; Becker, 1962). The importance of this concept has been acknowledged in economics (Cervellati and Sunde, 2005; Becker, 1962; Barro, 2001), business and management (Nyberg and Wright, 2015; Lepak and Snell, 1999) and, more recently, entrepreneurship (Unger et al., 2011; Marvel et al., 2016; Martin et al., 2013). While scholars conceptualised human capital mainly as a past investment (Becker, 1962; Mincer, 1958; Schultz, 1961), the focus recently shifted towards the outputs of human capital investments including knowledge, skills or abilities (Unger et al., 2011; Marvel et al., 2016; Martin et al., 2013). Despite the ongoing and growing use of the human capital construct in the entrepreneurial literature, its use remains difficult as there is an implicit assumption that the aspiring entrepreneur consciously knows about his/her human capital investments and his/her human capital outcomes from these investments. As human capital investments and human capital outputs are often assumed to be explicitly known, we currently lack a structured process of how to account for the non-formal and informal part of human capital investments and the tacit part of human capital outcomes.

As convincingly argued elsewhere, entrepreneurs are rationally bounded. They possess a limited cognitive capacity to process information (Simon, 1991; March and Simon, 1958) and are subject to several unconscious biases (Busenitz and Barney, 1997). Furthermore, the outcomes of human capital investments such as knowledge, skills or competences are often thought to be tacit (Nonaka, 1994; Polanyi, 1966), and thus not consciously known by the entrepreneur (Lepak and Snell, 1999). In this regard, I problematise (Alvesson and Sandberg, 2011) the implicit assumption that investments in human capital and their outcomes are explicitly known by the entrepreneur (Marvel et al., 2016). Instead, I depart from the assumption that human capital investments often come about through non-formal and informal learning experiences and human capital outcomes are often tacit (Lepak and Snell, 1999, p. 35) and embodied (Baetjer, 2000). Consequently, I pose the following research questions:

$R Q 1$. How to evaluate formal, non-formal and informal entrepreneurial investments in human capital?

$R Q 2$. How to evaluate explicit and tacit entrepreneurial outcomes of investments in human capital?

In this paper, I extend a typology on human capital proposed by Marvel et al. (2016, p. 616) which distinguishes human capital investments and human capital outcomes. I add the distinction of formal learning vs non-formal and informal learning to describe human capital investments in more detail. Furthermore, I conceptualise human capital outcomes on a continuum of tacitness to explicitness. I draw on the validation of prior learning to provide a structured process to guide the aspiring entrepreneur in making tacit human capital investments and tacit human capital outcomes explicit and thus develop their human capital. In this regard, capital development is an ongoing and social process in which knowledge, distributed amongst many must "interact to communicate their particular, often tacit knowledge" (Baetjer, 2000, p. 147). Through this ongoing interaction, the structure of human capital changes continually.

I contribute to the theory in the following respects. First, I contribute to the theory on entrepreneurial human capital, by extending the typology of human capital investments and human capital outcomes of Marvel et al. (2016) along the continuum of formal learning vs non-formal and informal learning, as well as tacitness vs explicitness. Furthermore, I propose a ratio between potential human capital (comprising human capital investments) and realised human capital (comprising human capital outcomes) and outline the theoretical implications. I contribute to a theory linking research on training and development and human 
capital. This is accomplished by describing a structured process how to validate explicit and tacit human capital investments and human capital outcomes, thus transforming them into a (partial) qualification and the legal right to follow a certain entrepreneurial activity. In focussing on the validation of prior learning I create an interface between entrepreneurial human capital theory and literature on training and development. Finally, I contribute to the theory of the validation of prior learning, by introducing two routes of validation: The formative route to validation and the summative route to validation that cumulates in one additional step, the triangulation within the assessment phase.

The remainder of this paper is structured as follows. Firstly, I give a brief overview of the scholarly debates on human capital and the validation of prior learning. Secondly, I propose a general process model on how the explicit and tacit parts of human capital investments and human capital outcomes can be transformed into a partial qualification, thus opening the route to entrepreneurship. Subsequently, I place the process model in the broader literature and discuss theoretical and practical implications.

\section{Conceptual model}

In this section, I introduce a conceptual process model of validation, depicting how potential and realised human capital can be transformed into a (partial) qualification (Figure 1). In Section 2.1, I introduce the notion of potential and realised human capital. In Section 2.2, I introduce the validation of prior learning and three different types of learning inputs and outcomes (formal, non-formal and informal), as well as a process consisting of four steps to assess learning outcomes. In Section 2.3, I outline how the validation of prior learning transforms potential and realised human capital into a (partial) qualification.

\subsection{Human capital}

Already Smith (1776, p. 368) recognised the "acquired and useful abilities of all the inhabitants or members of the society" as human capital. Subsequently, human capital was conceptualised as knowledge, skills and on-the-job training that have economic value (Becker, 1962). Thus, the human capital theory was introduced to examine the value of education (Becker, 1962; Schultz, 1961), stating that people have widely varying knowledge and skills some of which have a different economic value. Mincer (1958) concluded that human capital explains income inequality as we observe a "higher annual pay in occupations that require more training" (p. 301). Becker also (1962, p. 12) observed that "more highly educated and skilled persons almost always tend to earn more than others". Traditionally, human capital theory focussed on knowledge, skills (Schultz, 1961, p. 1), as well as general and specific human capital (Becker, 1962). For a recent review on human capital, theory Winterton and Cafferkey (2019). While human capital has been researched as a single concept in the past, recent research distinguishes between potential human capital or human capital investments and realised human capital or human capital outcomes/assets (Marvel et al., 2016; Martin et al., 2013; Unger et al., 2011).

Potential human capital or human capital investments reflect the input of learning processes. Learning can occur in a more formal, non-formal or informal way. Potential human capital can be conceptualised as the sum of learning and experiences a person has gained, thus far. Many forms of consumption constitute potential human capital or an investment in human capital such as "direct expenditures on education, health and internal migration to take advantage of better job opportunities" (Schultz, 1961, p. 1). However, investments in education or health alone simply comprise potential and not realised human capital outcomes [1]. Realised human capital or human capital outcomes reflect the output of human capital investments. Realised human capital can occur as formal, non-formal and

\section{Human capital investments and outcomes}

\section{$-2$}


EJTD
47,10

4

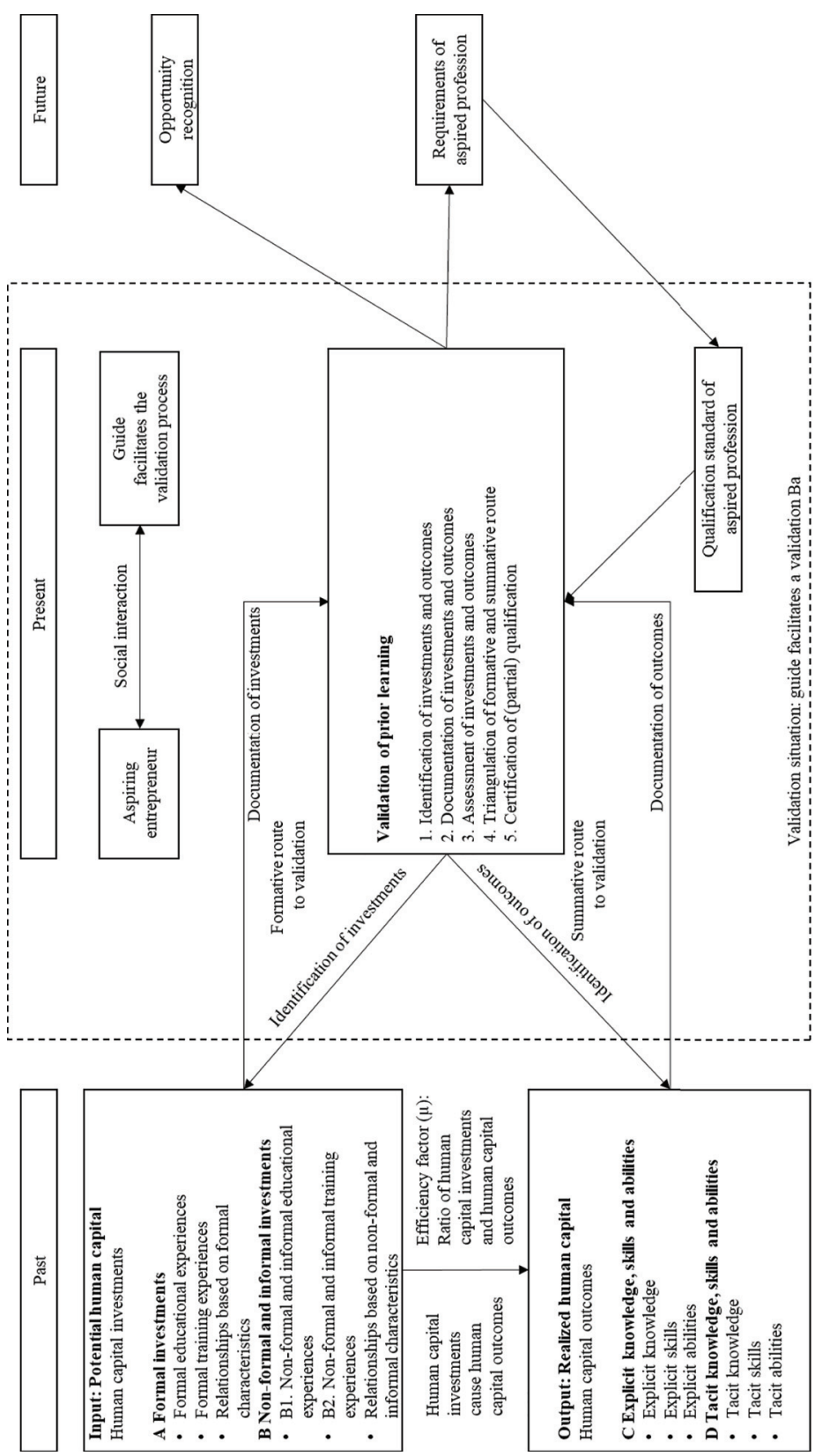

Figure 1.

Depiction of the conceptual process model 
informal learning outcomes. Realised human capital or human capital outcomes are "fully realised" knowledge, skills and abilities (Marvel et al., 2016, p. 608).

Potential human capital and realised human capital have distinct but interacting roles. Both subsets of human capital coexist at all times and are a necessary but not sufficient condition to assess and improve entrepreneurial performance. For example, an aspiring entrepreneur cannot use knowledge, which has not been developed previously (in this regard, outcomes need input). In the same vein, just because an aspiring entrepreneur went through formal education or earned a certain university degree, this does not imply that the acquired knowledge, skills and abilities are useful for the targeted entrepreneurial context. In this vein, a high potential human capital does not necessarily lead to good entrepreneurial performance. On the other hand, realised human capital is, thus, readily available and useful to improve entrepreneurial performance, regardless of the way of acquisition.

The ratio of potential human capital and realised human capital is termed as the efficiency factor $(\mu)$. The efficiency factor suggests that people vary in their ability to create value from their human capital investments as potential human capital can relate to the realised human capital in different ways. For example, for aspiring entrepreneurs with a low-efficiency factor, potential and realised human capital are far apart. For aspiring entrepreneurs with a highefficiency factor, realised human capital approaches the potential human capital. In the following, I introduce the validation of prior learning and demonstrate how the validation of prior learning helps to make non-formal, as well as informal entrepreneurial human capital investments and tacit entrepreneurial human capital outcomes more explicit. Furthermore, I discuss how the validation of prior learning can help to improve the efficiency factor $(\mu)$.

\subsection{Validation of prior learning}

While barriers to becoming an entrepreneur in the Anglo-Saxon area are generally sparse, continental Europe grants access to entrepreneurial activity (i.e. opening a business) through trading licences. The aspiring entrepreneur can pursue his/her trading licence by choosing one of two options. The input-based option requires the person to go through formal education and obtaining a formal qualification. In terms of human capital, this is an investment in human capital. The outcome-based option requires the person to prove via a validation or recognition of prior learning that he/she acquired the necessary knowledge, skills and abilities to perform on the same level as one with formal education. Thus, knowledge, skills and abilities are human capital outcomes. This is reflected in the shift towards competency-based education in the European vocational education and training system (Biemans et al., 2009; Bohne et al., 2017). The relevant standards of comparison are qualification standards maintained by different professional associations. Outcome-based orientation also implies that a person is granted access to entrepreneurial activity regardless of how the person acquired the necessary knowledge, skills and abilities. The validation of prior learning is then a "process of confirmation by an authorised body that an individual has acquired learning outcomes measured against a relevant standard" (Council of the European Union, 2012, p. 5).

The validation of prior learning aims at capturing three different types of learning: formal learning, non-formal learning and informal learning. Formal learning is "learning that occurs within an organised and structured context (formal education, in-company training, etc) and that is designated as learning” (Bjørnåvold, 2000b, p. 204). It is intentional from the learner's perspective. Non-formal learning comprises of "learning which is embedded in planned activities that are not explicitly designated as learning, but which contain an important learning element" and encompasses "what is sometimes described as semi-structured learning, that is learning embedded in environments containing a learning component" (i.e. quality management or massive open online courses) (Bjørnåvold, 2000b,

\section{Human capital investments and outcomes}

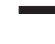


EJTD

47,10

p. 204). In this case, non-formal learning is also intentional from the learner's point of view. Informal learning is a subset of non-formal learning and derived from "from daily life activities related to work, family or leisure [... . it is often referred to as experiential learning and can to a certain degree be understood as accidental learning" (Bjørnåvold, 2000b, p. 205). For example, investments in parenting or entrepreneurial activities are often non-intentional and result in informal - thus, more tacit - learning outcomes. While it is relatively easy to validate formal learning through its intentionality and structured context, it is considerably more difficult to validate non-formal learning and all the more challenging to validate informal learning experiences as people are often unaware that they have learned a new skill (Bjørnåvold, 2000a, 2000b).

The validation of prior learning takes into account formal learning experiences but usually focusses on non-formal and informal learning. The validation of prior learning usually consists of the following four distinct phases: the identification, documentation, assessment and certification of prior learning experiences (Bjørnåvold, 2000a, 2000b). The identification of prior learning is a situated social process (Lave and Wenger, 1991) aimed at making tacit learning experiences explicit (Nonaka, 1994) through dialogue (Bohm, 2012) and structured reflection (Schön, 1983, 1990). The process occurs within a space that supports knowledge creation that I refer to as validation Ba (Figure 1). A validation Ba is a dynamic space-time nexus that provides the energy for knowledge-creating activities within the validation of prior learning. During phases of identification, the Ba can be conceptualised as a dialoguing Ba (Nonaka et al, 2000), however, during phases of documentation and assessment, it is rather conceptualised as a systemising Ba (Nonaka et al., 2000). The process of identification is usually guided and facilitated by an assessor. The documentation of learning outcomes aims to make previous learning visible (Bjørnåvold, 2000a, 2000b), usually by assembling a portfolio (Baeten et al, 2008) and collecting evidence from previous experiences encompassing formal, non-formal and informal learning experiences. The assessment of prior learning consists of the comparison of learning inputs and learning outcomes against a predefined and external standard (Cedefop, 2014, p. 28). A thorough assessment of these experiences is done using several methods and has two functions: a formative and a summative function. The formative assessment is "inputdriven, centred on the education and training procedure and linked to educational standards" (Colardyn and Bjornavold, 2004, pp. 79-80). In other words, the formative assessment is aimed at capturing educational investments. The summative assessment is "outcome-driven, centred on results achieved and linked to occupational standards (non-formal and informal learning) or educational standards (formal learning)" (Colardyn and Bjornavold, 2004, pp. 79-80). In other words, the summative assessment is geared towards capturing the outcomes of educational investments. Within the validation of prior learning, the "gold standard" of assessment procedures is the "triangulation of different assessment methods" (Cedefop, European Commission and ICF, 2017, p. 74) which includes portfolios (Baeten et al., 2008; McMullan et al, 2003; Brown, 2011) tests and examinations, interviews and simulations (Bohlinger, 2017, pp. 599-600). Finally, a legally authorised body certifies a full or partial qualification for the assessed prior learning (Council of the European Union, 2012, p. 5). This certification legitmatises the aspiring entrepreneur and allows them to open a business in their respective professional sector (Suchman, 1995).

\subsection{Linking human capital and the validation of prior learning}

Thus far, the very few publications that have explicitly dealt with linking human capital theory and the validation or recognition of prior learning (Andersson and Osman, 2008; Alexander et al, 2010) concentrate on potential power issues in South African context. However, Alexander et al. (2010) link the recognition of prior learning to the development of human 
capital through a social process. In the following, I describe the formative and summative route in regard to human capital investments and human capital outcomes (Figure 1).

Formative route to validation. The formative route to validation describes the identification, documentation and assessment of potential human capital or formal and nonformal/informal human capital investments. The identification of formal and non-formal/ informal human capital investments is a process of knowledge explication and combination (Nonaka et al., 2000).

In terms of identifying, documenting and assessing formal investments in human capital through educational experiences, formal training experiences and entrepreneurial relationships based on formal characteristics, the process is straightforward as certifications and degrees are often already available. The aspiring entrepreneur is facilitated through a guide to identifying all formal educational experiences, consisting of experiences in school, vocational education and training schools and higher educational institutions. Formal training experiences are those within vocational training or trainee-ships in larger organisations.

The identification of relationships based on formal characteristics points at formal knowledge and skills that cannot be imparted or developed by the aspiring entrepreneur in a reasonable time frame and must be acquired from an outside source. As argued priorly, capital development is an ongoing social process distributed amongst different people. For example, often small teams of entrepreneurs establish a company. Thus, human capital is socially constituted. Human capital investments may require professional relationships with certain people. This is the case, for example, with specialised lawyers within insurances or doctors that obtained those institutionalised competences which cannot be copied without violating the law. The documentation of formal human investments is straightforward as the aspiring entrepreneur is able to prove/demonstrate their institutionalised competences with their earned certifications and degrees. Documentation occurs through assembling a portfolio, providing written documentation of work experiences, collecting credentials, degrees, letters of reference and so forth. It is a guided social process of combining explicit knowledge about previous formal human capital investments. The assessment of formal education and training investments usually already completed and is administered by the organisation that offered education/training. In terms of assessing partnerships based on formal characteristics, the collected documentation is compared with the requirements of a professional standard.

The identification, documentation and assessment of non-formal/informal human capital investments prove to be a greater challenge and must be thoroughly facilitated by a guide. The identification phase consists of identifying non-formal/informal education and training experiences and relationships based on non-formal/informal characteristics.

The guide facilitates the aspiring entrepreneur to remember and explicate non-formal investments in human capital that occurred outside an institutional framework yet also possess an educational value. This can include obtaining a degree from massive open online courses, degrees from voluntary work such as a wood badge certificate from the scout movement. Documenting non-formal human capital investments in education and training may be tedious work as the aspiring entrepreneur has to "travel back in time" to collect relevant documents and add them to their portfolio. The assessment of non-formal education and training experiences is usually facilitated by comparing the content of the documented non-formal educational experience and training with the requirements of a professional standard.

Identifying, documenting and assessing informal human capital investment proves all the more difficult as the investment was often unintentional, and thus aspiring entrepreneurs are not aware that this could have been a relevant investment for the profession in mind. When identifying informal investments in human capital it is important

\section{Human capital investments and outcomes}


EJTD

47,10

to spot for experiences within the day-to-day life that did not contain any degree or certification yet possessed relevant learning elements. For example, experiences within scouting, working in a parish, raising a child, playing in a band and so forth. The identification of informal human capital investments requires a thorough and detailed guided analysis of the time spent so far. Documenting these experiences is more challenging than that within formal human capital investments but is supported by different possible ways of documenting. A person could, for instance, document informal human capital investments through photos, videos, references of friends and family and so on and so forth. It is obvious that this form of documentation is less trustworthy than documentation from formal human capital investments, as it is less institutionalised (Suchman, 1995). However, it can still provide context for the triangulation of assessment results. The assessment of informal investments in human capital happens by estimating the credibility of the documentation.

Identifying relationships based on non-formal and informal characteristics means explicating from the entrepreneur potential outside resources that do not depend on a formal qualification. For example, an aspiring entrepreneur could identify resources relative to his/ her context that help foster entrepreneurial success. Examples include technical experience, programming skills or marketing skills that must be acquired by the aspiring entrepreneur, but cannot be imparted or developed by themselves.

In sum, the assessment of formal and non-formalinformal human capital investments consists of the comparison of the investments against a predefined and external standard such as a qualification standard. Assessment should be the answer to the question of whether formal and non-formal/informal investments in human capital are sufficient to reach the standard of comparison. Thus, it is a process of combining various explicit documents.

Summative route to validation. The summative route to validation describes the identification, documentation and assessment of realised human capital or explicit and tacit human capital outcomes in terms of knowledge, skills and abilities. The summative route also comprises a knowledge-creating process consisting of explicating knowledge and a combination of different explicit knowledge sources (Nonaka et al., 2000; Nonaka, 1994).

Explicit knowledge in this context is defined as factual knowledge or "knowing that". This type of knowledge can be communicated from a possessor of said knowledge to another person and the other person becomes as knowledgeable as the original knowledge possessor (Ambrosini and Bowman, 2001). Often formal educational investments result in a certain degree of scientifically proven explicit knowledge (Sandberg and Pinnington, 2009). Explicit skills are skills of which people are aware. People know, for example, that they are able to ride a bicycle or that they know that they are able to repair a certain machine. In this regard, skills mean the explicit "ability to apply knowledge and use know-how to complete tasks and solve problems" (Council of the European Union, 2017, p. 20). Explicit acquired abilities are those which the aspiring entrepreneur has already acquired, for example, through formal networking or obtained contracts.

Identifying, documenting and assessing explicit human capital outcomes in terms of explicit knowledge, skills and abilities are again, relatively straightforward. General psychological constructs (Peterson et al., 2001) such as intelligence, personality or abstract thinking can be identified via standardised large-scale psychological testing. Here, the challenge is not within the identification, but within the reliability, objectivity and validity of identified and documented outcomes and the instruments used (Stenlund, 2010). Human capital outcomes in terms of explicit knowledge can, therefore, be reliably and validly identified, documented and tested within standardised oral and written tests. Explicit, taskgeneral and task-specific skills can be identified and documented through simulations and observations by an expert assessor. If an aspiring entrepreneur applies to be a carpenter, a 
simulation could help him/her to demonstrate their skills while doing carpentry work. The simulation can then be reflected via an explanation of what has been done (Bohlinger, 2017, p. 600). The assessment of explicit skills is, thus, the comparison of the performed and documented task with the respective qualification standards of what a carpenter should be able to perform and on which level of expertise. Explicit abilities resulting from relationships based on formal characteristics can be assessed via interviewing the respective professional or business partner.

Of course, whether an aspiring entrepreneur should be granted a licence to open a business should not depend on their intelligence, personality or work values the person adheres to. Rather, a certain level of demonstrated profession-specific knowledge and demonstrated profession-specific skills, as well as autonomy and responsibility, are arguably seen as the cornerstone to grant entrepreneurial access (Council of the European Union, 2008; Council of the European Union, 2017). From the outcome-based perspective, these are the main cornerstones that should be adopted to grant access to entrepreneurial activity.

However, what people know, what they are able to do and what abilities they have is often implicit or tacit (Ambrosini and Bowman, 2001; Polanyi, 1966). Tacit knowledge is difficult to write down and to formalise (Nonaka, 1994). Or, as famously noted on tacit knowledge: "the aim of a skillful performance is achieved by the observance of a set of rules which are not known as such to the person following them" (Polanyi, 1966, p. 62). Here, it becomes clear that tacit knowledge and tacit skills are difficult to disentangle and must be presented to the world through a skillful performance. Tacit abilities are difficult to copy and describe outcomes of relationships based on non-formal and informal characteristics. For example, if people worked together in a team over a long period of time, there are certain shared mental models developed (Johnson-Laird, 2004, 2013).

The identification, documentation and assessment of tacit human capital outcomes prove to be a formidable challenge as only a certain part of tacit knowledge, skills and abilities can be identified and documented, others are deeply ingrained (Ambrosini and Bowman, 2001, p. 816). To identify tacit knowledge, skills and abilities, the assessor guides the aspiring entrepreneur through their non-formal/informal educational and training experiences. Together, in reflective dialogue (Schön, 1983, 1990), they identify potential knowledge and skills that could have been potentially gained from these non-formal and informal investments into human capital. If these potential areas are identified, then tacit knowledge could be documented using causal mapping, Self-Q and storytelling as outlined by Ambrosini and Bowman (2001). Thus, explicating tacit knowledge and tacit skills requires the guiding assessor to possess a high level of skill themselves.

The assessment of tacit human capital outcomes can only be performed after its explication. If tacit knowledge and tacit skills can be made explicit to a certain degree through causal mapping, Self-Q and storytelling, it can again be compared to the external qualification standard. It is then a process of combining different explicit documents (Nonaka et al., 2000).

The results of the formative route and the summative route to the validation of human capital investments and human capital outcomes are then triangulated. In this case, triangulation is the process of judging convergent and divergent information of the two formative and summative routes of validation. While converging the information of both routes increases the reliability of the assessment, divergent information - if reflected properly - reveals important and complex aspects of the interaction between human capital investments and human capital outcomes that would have otherwise gone unrecognised without triangulation (Bechara and van de Ven, 2011, p. 343). The certification of human capital investments and human capital outcomes then becomes a formal qualification that

\section{Human capital investments and outcomes}


EJTD

47,10

recognises the investments made in human capital and the outcomes of human capital through four steps: the identification, documentation, assessment and triangulation of assessment results. Thus, certification may result in a partial or full qualification.

\section{Theoretical and practical implications}

In this section, I outline the theoretical and practical implications for the proposed conceptual process model. Currently, countries within the European Union are observing a shift away from input-oriented education (i.e. putting a focus on educational investments such as schools or universities) towards outcome-oriented education (i.e. putting a focus on outcomes of education) (Spady, 1994). This manner of thinking is strongly supported by lifelong learning (i.e. that a person acquires valuable knowledge, skills and abilities in all contexts of life). Here, the essential challenge is in making non-formal and informal learning explicit (Bjørnåvold, 2000a, 2000b). Currently, we observe a similar shift in thinking in conceptualising human capital. While the fathers of human capital theory emphasised the importance of human capital investments (such as expenditures in education, health and migration) (Schultz, 1961; Becker, 1962) that describe potential human capital, recent scholars in the field of human capital place more emphasis on realised human capital or the outcomes of human capital investments, as it is a better predictor for human capital (Marvel et al., 2016; Martin et al., 2013; Unger et al., 2011). This is nicely exemplified by Marvel et al. (2016, p. 608), "who state" that some people, although they may "have the same education or similar work experience, the readily available knowledge or skills possessed may be dramatically different". In this regard, future research on entrepreneurial human capital may well be more concerned with human capital outcomes than human capital investments.

Realised human capital or human capital outcomes can provide a competitive advantage for the entrepreneur, especially when human capital outcomes are profession-specific. On the other hand, potential human capital or human capital investments provide the entrepreneur with a higher degree of strategic flexibility to change decisions and flexibly adapt to market situations as comparably outlined by Zahra and George (2002). The efficiency factor $(\mu)$ can be improved by making tacit human capital outcomes such as tacit knowledge or tacit skills, explicit. Furthermore, the efficiency factor provides an explanation as to why some entrepreneurs who have invested a lot in human capital, do not maximise the value they could actually derive from their investments.

The proposed conceptual model has some practical implications for aspiring entrepreneurs and guides the facilitation of validation as well. Firstly, as a recent meta-analysis has shown (Unger et al., 2011), the outcome side is more important than the investment side in assessing entrepreneurial success. Aspiring entrepreneurs and guides facilitating the process of the validation of prior learning should focus on making the link between investments and outcomes a great deal explicit and should put their emphasis on entrepreneurial human capital outcomes rather than investments in entrepreneurial human capital. Thus, outcome-based human capital constructs are a better predictor of human capital than investment-based indicators. Secondly, recent approaches to human capital investments and outcomes distinguish between highly task-related human capital and low task-related human capital (Unger et al., 2011). In relation to entrepreneurial success, a high task-relatedness of human capital outcomes is a better predictor of entrepreneurial success than that of the low taskrelatedness of human capital outcomes. In other words, if the aspiring entrepreneur has already acquired domain-specific knowledge, skills or abilities, the chances for entrepreneurial success are higher (Unger et al., 2011). Aspiring entrepreneurs and guides facilitating the process of the validation of prior learning should emphasise identifying, documenting and assessing the knowledge, skills and abilities closely related to the ongoing tasks of the aspired profession. 
Thirdly, often tacit knowledge and tacit skills are seen as the main competitive advantage for organisations seeking a sustainable competitive advantage (Spender and Grant, 1996; Grant, 1996). As this is the case and as a large amount of tacit knowledge and skills cannot be made explicit anyway, aspiring entrepreneurs and assessors guiding the process should focus on validating both explicit profession-specific knowledge and demonstrated profession-specific skills. Recent developments within assessment procedures are well suited to assess and validate profession-specific human capital outcomes in terms of self-assessments [2] and standardised tests [3]. Fourthly, given the drastic disruptions of the labour market that will be most likely caused by automation and the fourth industrial revolution in the near future (Frey and Osborne, 2017), formal schooling and traditional credentials will lose importance on the labour market. In comparison, human capital outcomes such as tacit knowledge, skills and abilities will gain importance. As a result, we will be confronted with more diverse and nontraditional learning biographies. The theoretical model, as outlined in Figure 1, may be viable to serve as a conceptual foundation for algorithms and data mining approaches that are able to make these biographies comparable. As exemplified in Fahrenbach et al. (2019), these techniques can be used to comb social media platforms such as LinkedIn and Facebook to harvest insights about the non-formal and informal learning outcomes of individuals.

\section{Conclusion}

As the literature on entrepreneurial human capital investments and outcomes increased over the past 20 years (Marvel et al., 2016), it is helpful to provide a perspective from vocational education and training and especially the validation of prior learning on entrepreneurial human capital. I hope that this paper stimulates further research for human capital scholars and those in vocational education and training. I encourage further empirical research to test the viability of the conceptual model. Adopting appropriate qualitative and quantitative methods may help to find out how it could guide the work of validation practitioners. In addition, further research should shed light on the underlying mechanisms and contextual components of the efficiency factor $(\mu)$. In sum, I hope that the conceptual model outlined above will assist in making human capital investments and human capital outcomes more visible, and thus give it value. I encourage practitioners to create validation procedures that more explicitly consider human capital investments and human capital outcomes.

\section{Notes}

1. e.g. Huber (1991) argues in favour of a cognitive perspective on organisational learning in which learing represents potential rather than actual behavioural change.

2. www.meine-berufserfahrung.de/

3. www.arbeitsagentur.de/myskills

\section{References}

Alexander, G., van Wyk, M.M., Bereng, T. and November, I. (2010), “Legitimate peripheral participation (LPP) - the case for recognition of prior learning sites and knowledges in South Africa's transforming education system”, Teaching and Teacher Education, Vol. 26 No. 1, pp. 45-52.

Alvesson, M. and Sandberg, J. (2011), "Generating research questions through problematization", Academy of Management Review, Vol. 36 No. 2, pp. 247-271.

Ambrosini, V. and Bowman, C. (2001), "Tacit knowledge: some suggestions for operationalization”, Journal of Management Studies, Vol. 38 No. 6, pp. 811-829.

\section{Human capital investments and outcomes}

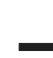


EJTD

47,10

Andersson, P. and Osman, A. (2008), "Recognition of prior learning as a practice for differential inclusion and exclusion of immigrants in Sweden", Adult Education Quarterly, Vol. 59 No. 1, pp. $42-60$.

Baeten, M., Dochy, F. and Struyven, K. (2008), "Students' approaches to learning and assessment preferences in a portfolio-based learning environment", Instructional Science, Vol. 36 No. 5-6, pp. 359-374.

Baetjer, H. (2000), "Capital as embodied knowledge: some implications for the theory of economic growth", The Review of Austrian Economics, Vol. 13 No. 2, pp. 147-174.

Barro, R.J. (2001), "Human capital and growth”, American Economic Review, Vol. 91 No. 2, pp. 12-17.

Bechara, J. and Van de Ven, A.H. (2011), "Triangulating philosophies of science to understand complex organizational and managerial problems", in Tsoukas, H. and Chia, R. (Eds), Philosophy and Organization Theory (Research in the Sociology of Organizations), Emerald Group Publishing Limited, Bingley, Vol. 32, pp. 343-364, doi: 10.1108/S0733-558X(2011)0000032014.

Becker, G.S. (1962), "Investment in human capital: a theoretical analysis", Journal of Political Economy, Vol. 70 No. 5, pp. 9-49.

Biemans, H., Wesselink, R., Gulikers, J., Schaafsma, S., Verstegen, J. and Mulder, M. (2009), "Towards competence-based VET: dealing with the pitfalls", Journal of Vocational Education and Training, Vol. 61 No. 3, pp. 267-286.

Bjørnåvold, J. (2000a), "Making learning visible. Identification, assessment and recognition of nonformal learning", Vocational Training: European Journal, Vol. 22, pp. 24-32.

Bjørnåvold, J. (2000b), "Making learning visible: identification, assessment and recognition of nonformal learning in Europe", CEDEFOP reference document, Office for Official Publ. of the Europ. Communities, Luxembourg.

Bohlinger, S. (2017), "Comparing recognition of prior learning (RPL) across countries", in Mulder, M. (Ed.), Competence-Based Vocational and Professional Education: Bridging the Worlds of Work and Education, Technical and Vocational Education and Training, Springer International Publishing, Cham, pp. 589-606.

Bohm, D. (2012), On Dialogue, Routledge Classics, 2nd ed., Taylor and Francis, Hoboken.

Bohne, C., Eicker, F. and Haseloff, G. (2017), "Competence-based vocational education and training (VET)", European Journal of Training and Development, Vol. 41 No. 1, pp. 28-38.

Brown, J.O. (2011), "Dwell in possibility: PLAR and e-Portfolios in the age of information and communication technologies", The International Review of Research in Open and Distributed Learning, Vol. 12 No. 1, pp. 1-23.

Busenitz, L.W. and Barney, J.B. (1997), "Differences between entrepreneurs and managers in large organizations: biases and heuristics in strategic decision-making", Journal of Business Venturing, Vol. 12 No. 1, pp. 9-30, doi: 10.1016/s0883-9026(96)00003-1, available at: www. sciencedirect.com/science/article/pii/S0883902696000031

Cedefop (2014), Terminology of European Education and Training Policy: A Selection of 130 Key Terms, 2nd ed., Publ. Office of the European Union, Luxembourg.

Cedefop, European Commission and ICF (2017), "European inventory on validation of non-formal and informal learning - 2016 update: synthesis report", Luxembourg.

Cervellati, M. and Sunde, U. (2005), "Human capital formation, life expectancy, and the process of development", American Economic Review, Vol. 95 No. 5, pp. 1653-1672.

Colardyn, D. and Bjornavold, J. (2004), "Validation of formal, non-formal and informal learning: policy and practices in EU member states", European Journal of Education, Vol. 39 No. 1, pp. 69-89.

Council of the European Union (2008), "Recommendation of the european parliament and of the council on the establishment of the European qualifications framework for lifelong learning".

Council of the European Union (2012), "Council recommendation of 20 December 2012 on the validation of non-formal and informal learning - 2012/C 398/01", Official Journal of the European Union C 398, pp. 1-5, available at: https://eur-lex.europa.eu/legal-content/EN/TXT/?uri=celex:32012H1222(01) 
Council of the European Union (2017), "Council recommendation of 22 May 2017 on the European Qualifications Framework for lifelong learning and repealing the recommendation of the European Parliament and of the Council of 23 April 2008 on the establishment of the European Qualifications Framework for lifelong learning - 2017/C 189/03”, Official Journal of the European Union C 189, pp. 15-28, available at: https:/eur-lex.europa.eu/legal-content/EN/TXT/?uri= CELEX:32017H0615(01)

Fahrenbach, F., Revoredo, K. and Santoro, F.M. (2019), "Valuing prior learning. Designing an ICT artifact to assess professional competences through text mining", European Journal of Training and Development, Vol. 44 Nos 2/3, pp. 209-235.

Frey, C.B. and Osborne, M.A. (2017), "The future of employment. How susceptible are jobs to computerisation?", Technological Forecasting and Social Change, Vol. 114, pp. 254-280.

Grant, R.M. (1996), "Toward a knowledge-based theory of the firm”, Strategic Management Journal, Vol. 17 No. S2, pp. 109-122.

Huber, G.P. (1991), "Organizational learning: the contributing processes and the literatures", Organization Science, Vol. 2 No. 1, pp. 88-115.

Johnson-Laird, P.N. (2004), "The history of mental models”, in Manktelow, K.I. and Chung, M.C. (Eds.), Psychology of Reasoning: Theoretical and Historical Perspectives, 1st ed., Psychology Press, Hove, New York, NY, pp. 179-212.

Johnson-Laird, P.N. (2013), "Mental models and cognitive change", Journal of Cognitive Psychology, Vol. 25 No. 2, pp. 131-138.

Lave, J. and Wenger, E. (1991), Situated Learning: Legitimate Peripheral Participation, Learning in Doing, Cambridge Univ. Press, Cambridge.

Lepak, D.P. and Snell, S.A. (1999), "The human resource architecture: toward a theory of human capital allocation and development", Academy of Management Review, Vol. 24 No. 1, pp. 31-48.

McMullan, M., Endacott, R., Gray, M.A., Jasper, M., Miller, C.M.L., Scholes, J. and Webb, C. (2003), "Portfolios and assessment of competence: a review of the literature", Journal of Advanced Nursing, Vol. 41 No. 3, pp. 283-294.

March, J.G. and Simon, H.A. (1958), Organizations, John Wiley and Sons, New York, NY.

Martin, B.C., McNally, J.J. and Kay, M.J. (2013), "Examining the formation of human capital in entrepreneurship: a meta-analysis of entrepreneurship education outcomes", Journal of Business Venturing, Vol. 28 No. 2, pp. 211-224.

Marvel, M.R., Davis, J.L. and Sproul, C.R. (2016), "Human capital and entrepreneurship research: a critical review and future directions", Entrepreneurship Theory and Practice, Vol. 40 No. 3, pp. 599-626.

Mincer, J. (1958), "Investment in human capital and personal income distribution", Journal of Political Economy, Vol. 66 No. 4, pp. 281-302.

Nonaka, I. (1994), “A dynamic theory of organizational knowledge creation”, Organization Science, Vol. 5 No. 1, pp. 14-37.

Nonaka, I., Toyama, R. and Konno, N. (2000), "SECI, Ba and leadership. a unified model of dynamic knowledge creation”, Long Range Planning, Vol. 33 No. 1, pp. 5-34.

Nyberg, A.J. and Wright, P.M. (2015), "50 Years of human capital research. Assessing what we know, exploring where we go", Academy of Management Perspectives, Vol. 29 No. 3, pp. 287-295.

Peterson, N.G., Mumford, M.D., Borman, W.C., Jeanneret, P.R., Fleishman, E.A., Levin, K.Y., Campion, M.A., Mayfield, M.S., Morgeson, F.P., Pearlman, K., Gowing, M.K., Lancaster, A. R., Silver, M.B. and Dye, D.M. (2001), "Understanding work using the occupational information network (O*net): implications for practice and research”, Personnel Psychology, Vol. 54 No. 2, pp. 451-492.

Polanyi, M. (1966), The Tacit Dimension, University OF Chicago Press, Chicago.

\section{Human capital investments and outcomes}


EJTD

47,10

Sandberg, J. and Pinnington, A.H. (2009), "Professional competence as ways of being: an existential ontological perspective", Journal of Management Studies, Vol. 46 No. 7, pp. 1138-1170.

Schön, D.A. (1983), The Reflective Practitioner: How Professionals Think in Action, Basic Books, New York, NY.

Schön, D.A. (1990), Educating the Reflective Practitioner: Toward a New Design for Teaching and Learning in the Professions, Jossey-Bass.

Schultz, T.W. (1961), "Investment in human capital", American Economic Review, Vol. 51 No. 1, pp. 1-17.

Simon, H.A. (1991), "Bounded rationality and organizational learning", Organization Science, Vol. 2 No. 1, pp. 125-134.

Smith, A. (1776), An Inquiry into the Nature and Causes of the Wealth of Nations, W. Strahan and T. Cadell, London.

Spady, W.G. (1994), Outcome-Based Education: Critical Issues and Answers, American Association of School Administrators, Arlington, VA.

Spender, J.C. and Grant, R.M. (1996), "Knowledge and the firm: overview", Strategic Management Journal, Vol. 17 No. S2, pp. 5-9.

Stenlund, T. (2010), "Assessment of prior learning in higher education: a review from a validity perspective”, Assessment and Evaluation in Higher Education, Vol. 35 No. 7, pp. 783-797.

Suchman, M.C. (1995), "Managing legitimacy: strategic and institutional approaches", Academy of Management Review, Vol. 20 No. 3, p. 571.

Unger, J.M., Rauch, A., Frese, M. and Rosenbusch, N. (2011), "Human capital and entrepreneurial success: a meta-analytical review", Journal of Business Venturing, Vol. 26 No. 3, pp. 341-358.

Winterton, J. and Cafferkey, K. (2019), "Revisiting human capital theory: progress and prospects", in Townsend, K., Cafferkey, K., McDermott, A. and Dundon, T. (Eds), Elgar Introductions to Management and Organization Theory Series. Elgar Introduction to Theories of Human Resources and Employment Relations, Edward Elgar Publishing, pp. 218-234.

Zahra, S.A. and George, G. (2002), "Absorptive capacity: a review, reconceptualization, and extension”, Academy of Management Review, Vol. 27 No. 2, pp. 185-203.

\section{About the author}

Dr Florian Fahrenbach is a postdoctoral researcher at the Institute for Data, Process and Knowledge Management at the Vienna University of Economics and Business (WU Vienna). Broadly speaking, his research interests are located in the intersection of information systems research and vocational education and training. His doctoral research (under the supervision of Prof. Alexander Kaiser) at WU Vienna employed the design science research methodology to develop an assessment system for professional competences with the goal to support the validation of prior formal, non-formal and informal learning in the Austrian Skilled Crafts and Trades sector. Florian was awarded a doctorate degree (with honors) at WU Vienna in September 2020. Florian Fahrenbach can be contacted at: florian.fahrenbach@gmail.com

For instructions on how to order reprints of this article, please visit our website: 